\title{
The Bali roadmap: new horizons for global climate policy
}

\author{
HERMANN E. OTT*, WOLFGANG STERK, RIE WATANABE
}

Wuppertal Institute for Climate, Environment and Energy, PO Box 1004 80, D-42004 Wuppertal, Germany

What is the significance of the 2007 United Nations Climate Change Conference in Bali? The formal outcomes, especially the 'Bali Action Plan', are described and commented on, along with the challenges for negotiating a post-2012 agreement in Copenhagen during 2008 and 2009. The article concludes that the outcome of the Bali meeting is insufficient when compared to the nature of the challenge posed by climate change. However, it can nevertheless be considered a success in terms of 'Realpolitik' in paving the way for the negotiations ahead, because some real changes have been discerned in the political landscape. The challenges for the road towards Copenhagen are manifold: the sheer volume and complexity of the issues and the far-reaching nature of decisions such as differentiation between nonAnnex I countries pose significant challenges in themselves, while the dependency on the electoral process in the USA introduces a high element of risk into the whole process. The emergence of social justice as an issue turns climate policy into an endeavour to improve the world at large - thereby adding to the complexity. And, finally, the biggest challenge is the recognition that the climate problem requires a global solution, that Annex I and non-Annex I countries are mutually dependent on each other and that only cooperation regarding technology in combination with significant financial support will provide the chance to successfully tackle climate change.

Keywords: Bali; climate negotiations; development and climate; Kyoto Protocol; policy frameworks; post-2012 negotiations; South-North

Quelle est la portée de la conférence des Nations Unis de 2007 sur le changement climatique qui s'est tenue a Bali? Les décisions officielles, en particulier le «plan d'action de Bali » sont décrites et analysées, ainsi que les difficultés pour les négociations sur un accord post-2012 qui se dérouleront à Copenhague en 2009. L'article conclut que le compromis final obtenu à Bali est insuffisant par rapport à la nature du défi climatique. Cependant, il peut être considéré comme un succès en terme de "realpolitik » car de véritables changements peuvent être discernés dans le paysage politique. Les obstacles sur la route vers Copenhague sont multiples: le volume même et la complexité des enjeux; la portée de certaines décisions notamment la différenciation entre les pays non inscrits à l'annexe 1 pose en elle-même des défis importants; enfin la dépendance du processus électoral aux Etats-Unis introduit un élément important de risque dans le processus général. L'émergence de la justice sociale en tant qu'enjeu fait de la politique climatique une entreprise à dessein d'améliorer le monde - la rendant de ce fait plus complexe. Finalement, le plus grand défi est dans la reconnaissance du fait que l'enjeu climatique nécessite des solutions à l'échelle planétaire, que les pays de l'annexe 1 et les pays non inscrits à cette annexe sont dépendants entre eux et que seule une coo pération technologique associée à un apport financier considérable offrira l'opportunité de relever avec succès le défi du changement climatique.

Mots clés: Bali; cadres de politiques; développement et climat; négociations post-2012; négociations sur le climat; protocole de Kyoto; sud-nord

When the climate meeting in Bali came to a close at $6.27 \mathrm{pm}$ on Saturday, 15 December 2007, the longest diplomatic battle in the history of global climate policy had finally ended, a full day behind schedule. Not even the legendary COP-3, which had seen the adoption of the Kyoto Protocol in 1997 , exceeded its schedule by this much. The length and 
fierceness of the negotiations bears witness to the fact that never before had climate policy been so complex, involving such a multitude of actors and issues. And, of course, never before had the prospect of negotiating concrete measures for both developed and developing countries been on the agenda.

Also never before had the science been so unequivocal and the public expectation been so strong. The Fourth Assessment Report of the IPCC, adopted in 2007, provided the strongest evidence for man-made climate change. It also provided the strong message that decisive action was required in order to keep the rise in global temperatures below a threshold that would present a chance of averting massive disturbances of the climate system.

The stage was further set by an unprecedented number of high-level diplomatic meetings in the same year dealing with climate change, ranging from the G8 Summit in Heiligendamm, Germany (6-8 June 2007) and the Gleneagles Dialogue meeting in Berlin (10-11 September 2007) to the special sessions of the UN Security Council and the General Assembly that involved most heads of state or government. Shortly before the Bali Conference, the Australian Labour Party had won the elections - with the promise to act strongly on climate policy. Ratification of the Kyoto Protocol was accordingly one of the first acts of the new Prime Minister, Kevin Rudd. The year 2007 can thus be regarded as a watershed in the global endeavour to stave off the looming danger of climate change through multilateral cooperation.

Compared to these preconditions and expectations, the process and the outcome of the Bali Conference appears to be rather meagre and inadequate. But, in real-world politics, where not only the sole remaining superpower (USA) but also other Parties, including Canada, Japan and Russia as well as OPEC, were doing their best to keep the agreement as weak as possible, the success of a conference must be measured differently. By this measure, the Bali Conference was not only characterized by a distinctively different atmosphere compared with the previous conference in Nairobi 2006, ${ }^{1}$ but indeed saw a significant shift in the battle lines; a rearrangement of positions and alliances that might well announce a decisive new era in global climate policy.

The most tangible result of the Bali Conference was the agreement on the 'Bali Action Plan' establishing an 'Ad-hoc Working Group on Long-Term Cooperative Action under the Convention' (AWG-Long Term) with the participation of the USA and developing countries. The more informal 'Dialogue' under the Convention that was initiated at COP-11 in Montreal in 2005 has thus been transformed into fully fledged negotiations. It continues the two-track approach: ${ }^{2}$ The AWG-Long Term will work in parallel with the already existing working group on Annex I Parties' commitments under Article 3.9 of the Kyoto Protocol, and with the same deadline (2009), in order to strike a comprehensive deal by COP-15/CMP-5 in Copenhagen.

Regarding commitments, the decision calls for developed country Parties' mitigation commitments 'including quantified emission limitation and reduction objectives', while 'ensuring the comparability of efforts among them' - a major setback to the drive of the USA and others to replace Kyoto-style binding absolute targets with voluntary pledges. The decision also calls for 'nationally appropriate mitigation actions by developing country Parties in the context of sustainable development'. Due to resistance by the USA, Canada, Japan and Russia, an indicative range of mitigation commitments by industrialized countries that is considered necessary by the IPCC to stay below two degrees (25-40\% compared to 1990 levels) was not included in the text, but was relegated to a reference in a footnote.

One major step forward lies in the language used, because it moves away from the hitherto sacrosanct division between 'Annex I' and 'non-Annex l' countries. Using the terms 'developed country Parties' and 'developing country Parties' instead, this decision opens the gate for new combinations of commitments suitable for the different stages of economic development, emissions and mitigation potential in which developing countries find themselves. Finding appropriate indicators and methods for differentiation between developing countries will be one of the huge tasks of the next two years ahead. ${ }^{3}$

The Bali Conference also saw developments in financing and technology transfer - hitherto always treated as side issues. This has led to widespread dissatisfaction on the part of non-Annex I countries, which increasingly demand more substantial offers from Annex I countries. Very important, the Adaptation Fund was made operational, and the Kyoto Protocol is thus finally ready to be fully implemented -2 weeks before the start of its first commitment period.

The major breakthrough on technology and finance, however, was achieved in the Bali Action Plan. According to the decision, mitigation actions by developing country Parties must be 'supported and enabled by technology, financing and capacity-building, in a measurable, reportable and verifiable manner'. This in the end proved to be the 'make or break' formulation in the final hours of the conference. True, the UNFCCC already commits industrialized countries to technology transfer and financial support of mitigation 
measures undertaken by developing countries (Articles 4.3 and 4.5). But it has become more and more obvious that mitigation activities by developing countries on the scale required to combat dangerous climate change will require support from the North on an order of magnitude that is far beyond anything that has so far been considered. Nevertheless, the diplomatic acknowledgement had so far been missing in the post-2012 negotiation process. Moving the words 'measurable, reportable and verifiable' away from developing countries' mitigation actions to the technological and financial support testifies to the enhanced importance of developing countries and the emerging economies in climate negotiations. Developing countries thus have a clearly worded anchor, in line with the formulations already embodied in the UNFCCC (Articles 4.3 and 4.5), that any commitments on their part have to be matched by clearly identifiable and transparent support from industrialized countries.

The Bali Action Plan, therefore, despite its rather timid language, represents a real achievement in real-world politics. Considering that the most powerful country has moved from a position of climate denial a few years ago to participation in an international dialogue on tackling climate change is a positive step, even though the USA, Canada and Japan had underwritten the acknowledgement in principle of multilateral approaches already at the G8 Summit in Heiligendamm. The creation of US climate policy remains one of the biggest mysteries of our time, which future historians will find difficult to comprehend. Al Gore urged the delegates, in his address to a packed plenary, to overlook the current obstructive tactics and instead anticipate where the USA will be in two years' time, due to national elections. With these words, Gore provided the script to a drama that unfolded in the last frenzied hours of the conference. The US delegation was collectively forced to budge by delegates and all other participants and had to withdraw its reservations to the final agreement. The tension that had built up during the conference by the consistent obstruction was unleashed in a collective uproar and the USA 'got out of the way', as the delegate from Papua-New Guinea had demanded earlier.

In contrast to many apprehensions before the conference, developing countries showed an unprecedented willingness to take up an active role in the fight against climate change. This testifies to the mature character of these countries and governments. Bali thus effectively annihilated the main excuse of the present US administration for not acting on climate change; namely that developing countries are unwilling to make a contribution. It also points to the great potential for cooperation with the European Union on the design of the post-2012 agreement. The EU, for its part, spent the first week of the conference trying to act as a bridge leading the USA and their allies back into the fold, but in the second week reinforced its position and strongly fought back attempts to water down the draft decisions. While weak on substance, Bali thus opened a vista on what shape a post-2012 deal could take over the next two years.

The Bali Action Plan thus paves the way for the negotiations towards a post-2012 agreement in 2009 at Copenhagen. However, the way is not a highway but a rather bumpy road filled with potholes and obstacles. There is, first, the complexity and sheer workload. The delegations will have to manage negotiations in six different arenas: the COP and the CMP of Convention and Protocol, the two subsidiary bodies of both treaties and the Ad-hoc Working Groups under the Convention and the Protocol. The AWGLong-Term initiated by the Bali Action Plan has tentatively scheduled four sessions, with the first session taking place not later than April 2008. The Ad Hoc Working Group on Further Commitments for Annex I Parties under the Kyoto Protocol (AWG-Article 3.9), according to its work plan adopted in Bali, will also hold four meetings in 2008 and 2009 , respectively. In addition, there will be several meetings of the 'major economies' initiative by the US government and a flurry of other formal and informal meetings on the same issues. If the utter exhaustion of even several 'veterans' of the diplomatic circus during the final hours of the Bali Conference is not to become a common sight in these negotiations, the participants will have to find ways of accommodating their capacities to these demands.

They will also have to find ways to deal with the enormous work load ahead, from negotiating deepened commitments for those countries that are already bound under the Kyoto Protocol, new commitments for developing countries (including methods for differentiation), integrating the USA with new commitments, adaptation, deforestation, vastly improved financial mechanisms, technology cooperation, to improving the market mechanisms that are still in the first stages of their existence. All these processes have to be kept under surveillance, kept apart, streamlined where necessary, and - in the end - all those different threads have to be combined into one gigantic package deal. Tying all the pieces together has already proved difficult enough in Bali.

Second, the issues at hand involve decisions with farreaching political implications. For example, the necessary differentiation of commitments for developing countries implies a rethinking of the relations within the G77/China. Differentiation is not unthinkable and has happened already in other contexts such as the trade negotiations, where interests are also extremely diverse among the group. But it will require major political will and courage. The language in 
the Bali Action Plan indicates that the G77/China has realized the challenge.

Third, the final outcome of the negotiations up to Copenhagen will crucially depend on a single national political process - that of the USA. Despite the breathtaking developments at the level of dozens of states, hundreds of cities and millions of citizens, it is at the federal level of the US government where the most important decisions are being taken. A new president of whatever political colour may change the basic stance on climate policy. But close observers of the political process in the USA are warning that the USA after 2009 will still be a long way from where the rest of the world is already. Getting a climate agreement ratified by Congress may prove to be impossible for the next president. One possible route out of this deadlock could be substituting the ratification of the international agreement by, first, the establishment of a strong national climate programme in the USA, including ambitious reduction targets, and, as a second step, a unilateral declaration that the USA considers itself bound to these targets by international law. ${ }^{4}$ There is a small chance that such a binding international declaration under international law in lieu of ratifying the international agreement could satisfy the rest of the world. This would, however, require quite a degree of goodwill on the part of the industrialized partners and especially the emerging economies.

Fourth, Bali saw the emergence of the social justice movement on climate change. The climate negotiations have never been pure environmental diplomacy because economic considerations have always loomed large at every conference. Bali, however, saw many new faces in the halls and corridors: social justice activists at the national as well as the international level have discovered in recent years that climate change is fundamentally altering the way they have been working. This is true for the impacts of climate change, which threaten to undermine social progress, especially in the South. But it is also true of the response measures to climate change; for example, in the search for alternatives to fossil fuels, the demand for agrofuels is threatening large forest areas in the Amazon and the Pacific, affecting local ecosystems as well as subsistence economies living on those forests. Furthermore, the sheer volume of the financial resources required - in the range of hundreds of billion dollars per year - will dwarf the traditional flows in official development aid. Therefore, organizations ranging from Oxfam to the Third World Network and Focus on the Global South are now taking the issue of climate change seriously. As a result of their participation, the content and tone of the negotiations are beginning to change and their support has led to greatly increased confidence on the part of the larger developing countries.
This is, fifth, the biggest task at hand: forging an alliance between North and South - with the emerging economies on mitigation and with the poorer countries on adaptation. ${ }^{5}$ It has become clear that the threat of destabilization of the climate system can only be solved by a truly global effort. Around $50 \%$ of emissions at the moment stem from Annex I countries, with the remaining $50 \%$ from non-Annex I countries, and this is rising rapidly. Each side thus has the potential to lead the world into climate chaos if it continues on a course of businessas-usual - some new form of 'mutually assured destruction'. There is a difference, though: in the cold war, both sides had to refrain from doing something, i.e. from pushing the button. Averting climate change, however, requires something positive, it demands activity and cooperation.

The Bali coalition between developing countries and the EU that allowed for passage of the Bali Action Plan provides some reason for optimism that it will be possible to strike an adequate post-2012 agreement. Nevertheless, while the emerging economies have made a first move and gave clear signals that they are willing to bear their fair share, the EU will have to significantly step up its efforts not only in the area of mitigation but also with regard to technology cooperation and finance. Substantial contributions from the South will require equally substantial financial and non-financial support from the North, a truth that only a few negotiators are willing to acknowledge, at least publicly. Building a 'green alliance' with the South will require a significant change in attitude. But the rewards could also be substantial - for Europe, for South-North relations, and for the world.

\section{Acknowledgements}

The authors would like to thank Florian Mersmann and Christof Arens for their support in Bali.

\section{Notes}

1. See Sterk, W., Ott, H.E., Watanabe, R., Wittneben, B., 2007, 'The Nairobi Climate Change Summit (COP 12MOP 2): taking a deep breath before negotiating post2012 targets?' Journal for European Environmental and Planning Law 2, 139-148.

2. See Wittneben, B., Sterk, W., Ott, H.E., Brouns, B., 2006, 'The Montreal Climate Summit: starting the Kyoto business and preparing for post-2012: The Kyoto Protocol's First Meeting of the Parties (MOP 1) and COP 11 of the UNFCCC', Journal for European Environmental and Planning Law 2, 90-100.

3. See e.g. Ott, H.E., Winkler, H., Brouns, B., Kartha, S., Mace, M.J., Huq, S., Kameyama, Y., Sari, A.P., Pan, J., 
Sokona, Y., Bhandari, P.M., Kassenberg, A., La Rovere, E.L., Rahman, A., 2004, South-North Dialogue on Equity in the Greenhouse: A Proposal for an Adequate and Equitable Global Climate Agreement, GTZ Climate Protection Programme, May 2004 [available at www.wupperinst.org/uploads/tx_wiprojekt1085 proposal.pdf]; see also www.fiacc.net
4. See Ott, H.E., 2007, Climate Policy post-2012 - A Roadmap: The Global Governance of Climate Change, Discussion paper for the 2007 Tällberg Forum, Tällberg Foundation, Stockholm [available at www.wupper inst. org/uploads/tx_wibeitrag/Ott_Taellberg_Post 2012.pdf].

5. See Ott, H.E. (2007), as above, Note 4. 